\title{
1 The Technocrats
}

\section{Challenges of Governance in a Polyglot Society}

\begin{abstract}
Precision, speed, unambiguity, knowledge of files, continuity, discretion, unity, strict subordination, reduction of friction and of material and personal costs - these are raised to the optimum point in the strictly bureaucratic administration.
\end{abstract}

- Max Weber

\section{Introduction}

How was it that British colonizers were able to assert claims of governance over whole populations of people to whom they could not actually speak? This puzzle assumes special salience in Malaya, whose linguistic diversity became typecasted: there were so many tongues on the peninsula, and not for nothing was it dubbed by contemporaries as the 'Babel of the East'. Victor Purcell (1896-1965), a prominent Chinese Affairs officer, addressing his European compadres over the weekly luncheon at the Rotary Club in 1935, put it like this:

There is, I believe, no record of the number of tongues spoken at the original Babel but I have an idea that if the truth were known Singapore would be found to have put its ancient prototype into the shade ....

Come for a walk with me in Singapore. I will show you outside a shop an Arab from the Hadramaut chanting aloud his Koran in Arabic. At the corner I will show you a Cantonese professional storyteller recounting to a crowd extracts from the 'Three Kingdoms' or 'The Dreams of the Yellow [sic] Chamber'... There is a cinema poster in Tamil of a forthcoming film at the Marlborough stuck up on a pillar by the five-foot way.

Come a little further and I will point out to you where newly arrived Dutch delicacies are set out in Dutch on a board. The Japanese hotel has its name in Japanese; the Greek sailor over there is trying to speak in broken French to a Madrasi who is selling cigarettes. I had in my office the other day a person who knew nothing but Yiddish speaking to someone who knew nothing but French through the intermediary of an interpreter of Yiddish who spoke English and myself speaking French. If you buy a bottle of Eno's from the Madrasi's stall the 
wrapper will make a valiant attempt in ten languages to describe the contents and its properties to anyone who may chance to buy it.

When we remember that there are 1500 languages in the world and a large proportion of them are spoken in Singapore at some time or another you may believe that this attempt must often fail. Recently my staff and I were completely baffled by a Somali cattle dealer. ${ }^{1}$

In fact, the 1911 census had counted 54 languages spoken in Singapore alone, which by that time had achieved a reputation for being perhaps the most cosmopolitan city in Asia. ${ }^{2}$

How was this Babel tamed? How did colonizers govern, or try to govern, polyglot subjects? What challenges did they encounter in doing so, and what can we learn about the nature and tensions of colonial rule in examining them? The linguistic aspect of the imperial endeavour often goes unremarked, but invisibility belies ubiquity. Every act of imperial governance involves the management of alien polyglot spaces, and thus every imperial bureaucracy suffers, to varying degrees, from the lack of language expertise. Examining the colonial bureaucracy from the perspective of the colonial state's linguistic challenges, more often than not, reveals a suite of deep and distinct anxieties: a systemic mockery of the Weberian ideal. To highlight some of these anxieties, this chapter focuses on the creation of what I call a language technocracy in British Malaya, which I understand to be an administration whose rationale for allocating work and resources was fundamentally underpinned by its language needs.

The problem of the lack of language expertise was not, of course, limited to the colonial situation in Malaya. There, as in Hong Kong, South Africa, India, Southern Rhodesia, and many other places, British rule regarded plurilingual colonial situations as a hindrance to proper and effective governance, and language expertise was valued as a critical tool in the exercise of power. ${ }^{3}$ Burma, colonized formally by the British in 1888, was bewilderingly polyglot, with even conservative estimates placing the number of spoken languages at seventy, and ranging up to

1 'Babel in Singapore', address by Victor Purcell at the weekly luncheon of the Rotary Club, Adelphi Hotel, Singapore, 16 October 1935, reprinted in 'Basic English as Cure for Malayan Language Confusion', ST, 17 October 1935.

2 Hayes Marriot, Census Report of the Straits Settlements, 1911 (Singapore: Government Printing Office, 1911). See also A. M. Pountney, Federated Malay States: Review of the Census Operations and Results, 1911 (London: Government of the Federated Maiay States, 1911).

3 On Southern Rhodesia, for example, see Diana Jeater, 'Speaking Like a Native: Vernacular Languages and the State in Southern Rhodesia, 1890-1935,' Fournal of African history 42, no. 3 (2001), 449-68. The classic statement for India is Bernard Cohn, Colonialism and Its Forms of Knowledge: The British in India (Princeton, NJ: Princeton University Press, 1996). 
a hundred. ${ }^{4}$ And of course, there are few nations which at first glance present a more spectacular tableau of linguistic diversity than India, with some 180 languages, depending on how one counts them. ${ }^{5}$ Other empires faced similar problems. Perhaps the most comparable case study is the Dutch empire in the Netherlands East Indies, which faced a similar brew of languages across the archipelago, and to which comparative reference will be made where appropriate.

Yet the perceived problem of languages in British Malaya, I suggest, was especially compounded by the extent and diversity of its Chinese emigrant populations. Sojourning Chinese frequently comprised proportionately the largest migrant populations in any single colonial territory, with the British port cities of Singapore and Penang becoming the only majority-Chinese colonial urban settlements in Southeast Asia by the mid-nineteenth century. Examining Britain's language technocracy in Malaya thus illuminates, in usefully stark historical particulars, the general challenges of monoglot governance in any polyglot colony where those who sought to govern were but a thin veneer of prospective rulers, who for all governmental intents and purposes were both illiterate and mute. In this chapter, I examine three specific challenges to governance which the lack of language command created in Malaya: translation crises in the law courts; crises of morality and authority within the colonial state; and crises of incompetence in the civil service. Together, these paint a picture of a systemically brittle colonial state, one which seemed condemned by the very nature of its rule to exist in a state of perpetual unease.

\section{The Early Days of British Rule}

In a pattern of conquest entirely in line with European imperial encroachment in other parts of Southeast Asia, the British colonized Malaya incrementally. This is reflected in the piecemeal quality to their administration and, as we will see, in the patchy and extempore assembling of the language technocracy. The French had been provoked into more formal conquest of Indochina by 1858 after threats to Catholic missionary interests, and the Dutch had placed the Indies (in particular Java) under direct rule of the Dutch government in 1800, with the process of 'creeping annexation' complete by 1910 , as the peripheries of the Indies outside

${ }^{4}$ Justin Watkins, 'Burma/Myanmar,' in Language and National Identity in Asia, ed. Andrew Simpson (Oxford: OUP, 2007).

5 Though the really significant languages number only about a dozen; see Christopher R. King, One Language, Two Scripts: The Hindi Movement in Nineteenth Century North India (Oxford: OUP, 1994). 
the Javanese center were gradually 'pacified'. British rule in Southeast Asia, too, was 'late and reluctant', even more belated than that of the French or Dutch. It advanced primarily by commercial consideration via the East India Company (EIC) and its early mercantile buccaneers: a 'cheap and non-committal alternative to annexation' ${ }^{6}$ Penang, the small and verdant northern island at the neck of the Malaccan Straits, was leased from the Sultan of Kedah and eventually became a Residency under the Governor of Bengal in 1786. Another profitable chunk of the peninsula, the sugar plantations of Province Wellesley, was added in 1800. Meanwhile, in the south, Stamford Raffles, wielding the might of the British navy, extreme political cunning, and a certain personal charm, secured a little slab of land at the southernmost tip of the peninsula from the Temenggong of Johor in 1819. Over the next decade or so, Singapore, as it was now known, flourished, and was brought under the direct control of the Governor-General of India.

Raffles' acquisition, undertaken without direct orders from Britain, was one of several points of contestation between Britain and the Dutch, both jousting for influence and commercial rights in the Southeast Asian archipelago. These disputes were settled once and for all in the Anglo-Dutch Treaty of 1824, when the archipelago was divided formally into spheres of influence demarcated by the Straits of Malacca. The British would be dominant to the north of the Straits, while the Dutch took possession of the whole of Sumatra and the archipelagic constellation of what would eventually become the Netherlands East Indies. Two years later, the northern and southern flanks of what would become British Malaya began to crystallize. The Burney Treaty of 1826, signed in Bangkok between EIC agent Henry Burney and King Rama III of Siam, established Siamese claims over northern Malay states, in exchange for Siam's formal recognition of British possession of Penang - there is no better statement of the disinterest British actors at this point had in anything that did not directly advance their commercial interests. Shortly afterward, Penang, Singapore, and Malacca were formed into a single Presidency, and the British Straits Settlements thus emerged: three tiny blips on the western fringe of the peninsula, surrounded by large sprawling Malay kingdoms in the south - Perak, Selangor, Johor - and Siam's acknowledged possessions in the north - Perlis, Kedah, Kelantan, and Terengganu. ${ }^{7}$

${ }^{6}$ J. de V Allen, et al., A Collection of Treaties and Other Documents Affecting the States of Malaysia, 1761-1963, vol. I (London: Oceana Publications, 1981), 6.

${ }^{7}$ For background to the expansion of British rule across Malaya, see Charles Donald Cowan, Nineteenth-Century Malaya: The Origins of British Political Control, vol. 11 (London: OUP, 1961). 
From this point on, the consolidation of British rule slowly expanded into the policy of active intervention through the enlargement of the scope, size, and nature of its administration. The transfer of the Straits Settlements from the India Office to the Colonial Office in 1867 marked the beginning of these changes, for it was a signal that it warranted administering as a Crown Colony in its own right, rather than as a far-flung and lesser province of India. The British Residency system, introduced in 1874, marked a new frontier of British imperialism in Malaya, and by 1914, the large Malay kingdoms had, one by one, came under the aegis of formal British rule, with Johor joining last. At the time of the 1867 transfer to the Colonial Office, the Straits government was a mere whisper in the lives of its heterogeneous, polyglot Asian populations. By 1941, on the eve of the Japanese invasion, the British had brought the whole polity into its executive, judicial, and social embrace, laying the foundations for the modern state.

\section{The Language Technocracy}

It is the creeping nature of this annexation that, I want to suggest, did much to shape the character of the British language technocracy. Accompanying this piecemeal expansion of British rule was the rise of a civil service. In their work, we can observe the challenges faced on the ground by these men (and they were all men), whose business it became to govern the many-tongued populations they could not reliably speak to. The challenges of taming Babel produced distinctive linguistic anxieties. The picture of the administration which I paint here is one far removed from the Weberian ideal. Instead of rationalized, bureaucratically driven 'laboratories of modernity' - instead of precision, speed and unambiguity - language revealed a deep chaos and incompetence in the heart of the colonial technocracy. ${ }^{8}$

Translation, as Tim Harper suggests, was a key predicament of the colonial state in Malaya. From its very inception, the state was hampered by the multitude of languages that roiled and bumped up against each other within this relatively small geographical area. ${ }^{9}$ From the earliest days of the British empire, American and European travel literature to Singapore can be found saturated with the bewilderment of the

${ }^{8}$ For a critique of assumptions of reason and rationality in colonial bureaucracies, see e.g., Frederick Cooper and Ann Laura Stoler, Tensions of Empire: Colonial Cultures in a Bourgeois World (Berkeley: UCP, 1997); Ann Stoler, 'Affective States,' in A Companion to the Anthropology of Politics, eds. David Nugent and Joan Vincent (Oxford: Blackwell, 2008).

9 T. N. Harper, 'Globalism and the Pursuit of Authenticity: The Making of a Diasporic Public Sphere in Singapore,' SOFOURN (1997), 268. 
situationally illiterate: all who set foot on shore found themselves immediately out of depth in a sea of tongues. Alfred North (1807-1869), a Presbyterian missionary from Exeter, set sail in 1835 for Singapore. He emerged from a year's journey at sea into the free port, where it took him less than a day to drown. 'O these tongues! $\mathrm{O}$ these tongues!' he lamented to his diary, less than a month after his arrival. 'We at Singapore can indeed boast of the most delightful and healthy climate in the world, of cheap living, an excellent government, free trade, and every manner of comfort and convenience. But ... Providence designs this world to be a place of trouble ... . The requisite evil, if I mistake not, is found in our unutterable confusion of tongues. ${ }^{10}$ Alfred North's Babel was a thorny, troublesome one. In the cosmopolitan port city of Singapore, he wrote, the languages spoken included the gamut of European ones - English, French, German, Dutch, Italian, Spanish, Portuguese - as well as a plethora of regional ones - Tamil (known at the time as 'Kling'), Bengali, Siamese, Javanese, Bugis, Balinese, 'Cochin-chinese', and a language North called 'Indo-Portuguese', which 'the European Portuguese can hardly, if at all, understand'. And of course there were the Chinese 'dialects' - though these, North observed, were 'so different that they need interpreters when they speak to each other, as much as an Englishman does when he speaks to any one of them... [that they] ought therefore to be reckoned as six languages'. ${ }^{11}$

These 'dialect' divisions were produced by distinctions of both language as well as place of origin, for these dialects were in large part regional languages. ${ }^{12}$ For the most part, Chinese communities in Southeast Asia trace their ancestries to the southern coastal provinces of China, particularly Fujian and Guangdong, the two largest qiaoxiang ('home towns') of the Nanyang Chinese. Language overlapped with native place to produce sub-ethnic identities within the wider immigrant populations - southern and northern Min (Hokkien), as well as Chaozhou, Hainan, Fuzhou, Cantonese, and Hakka. Cantonese and Hakka became the predominant languages of a new influx of migrants on the mining frontier in Malaya after the opening of Hong Kong and other treaty ports from 1840 onward. It is also worth noting that the distribution of this Chinese-speaking diversity in Southeast Asia was

${ }^{10}$ Alfred North, 'The Journal of Alfred North, 1 August 1835 - 27 July 1836: Transcribed by Ian Proudfoot,' <http://mcp.anu.edu.au/proudfoot/North.pdf> (accessed 8 April, 2013), entry for 1 March 1836.

${ }_{11}$ Ibid., entry for 20 February 1836, 259.

12 On the problematic use of 'dialect' to describe these regional Sinitic languages, see Victor Mair, "What Is a Chinese "Dialect/Topolect"?: Reflections on Some Key Sino-English Linguistic Terms,' Sino-Platonic Papers 29 (1991). 
uneven. At the time North was in Singapore, in 1836, the total population of the island was 25,540, of which well over one-third were sojourners from China. ${ }^{13}$ By 1901 they were 164,000 strong, representing more than $70 \%$ of Singapore's total population. More significantly, however, the population was highly heterogeneous, featuring Hokkien, Cantonese, and Teochew groups in comparably even numbers. ${ }^{14}$ In contrast, Chinese communities in other major port cities like Batavia and Manila were proportionally smaller as well as more homogenously distributed. In the Philippines, for example, the second largest dialect group, Cantonese speakers, comprised a mere 5\% of the total Chinese population around the turn of the twentieth century, and at most $10 \%$ of urban Manila's Chinese population. ${ }^{15}$

In the earliest years of British settlement, the solution to the 'problem' of Chinese linguistic diversity was highly pragmatic: Francis Light simply appointed kapitans, or respected leaders, of each language community to serve as intermediaries between the English-speaking colonial state and those it sought to govern. The kapitan system - the practice of governing communities through their headmen - was not, of course, Light's invention, but had also been in use by earlier Europeans to govern the immigrant populations of their colonial settlements. In Spanish Manila, a gobernadorcillo de chinos or capitán was appointed to act as judge in civil actions, and liaise between the Chinese community and the Spanish government. ${ }^{16}$ In the Dutch East Indies, the kapitan system was implemented most comprehensively on Java, where Chinese populations were most numerous. It reached its most advanced associational form in the Batavian Kong Koan (gongguan), the Council of Chinese Officers, whose member kapitans were appointed by colonial authorities and served long, powerful terms as social and political intermediaries between Chinese communities and the Dutch government. ${ }^{17}$

But as Chinese populations in Southeast Asia swelled, the practice of ruling through chiefs eventually became inadequate. In the Dutch case, this happened later, and was directly affected by the rise of Chinese

${ }^{13}$ North, 'Journal of Alfred North,' 258.

${ }^{14}$ William Pickering, 'Chinese Secret Societies and Their Origin,' FSBRAS 1 (1878), 63-84. For an overview, see Victor Purcell, The Chinese in Malaya (Oxford: OUP, 1948). For data on distribution of Chinese dialect groups in Singapore, see Mak Lau-Fong, The Dynamics of Chinese Dialect Groups in Early Malaya (Singapore: Singapore Society of Asian Studies, 1995).

${ }^{15}$ Edgar Wickberg, The Chinese in Philippine Life, 1850-1898 (Manila: Ateneo University Press, 1965), 177.

${ }^{16}$ Ibid., 37.

17 See Leonard Blussé and Chen Mongheng, eds. The Archives of the Kong Koan of Batavia, vol. 59, Sinica Leidensia (Leiden: Brill, 2003). 
nationalism. The legitimacy of the Kong Koan officers in the eyes of an increasingly diverse and politically aware Chinese community over the early twentieth century began to diminish. The old kapitan system, subjected to increasing criticism as an anachronistic residue of old China and perceived (rightfully) as a Dutch-sponsored organization, was eventually abolished. In the British case, however, the magnitude and diversity of the linguistic problem seems to have generated a significant pull toward the establishment of the language technocracy early on, more so than the push factor of kapitan irrelevance. The transfer of the Straits Settlements to the Colonial Office was, in part, a decision affected by the growing perception that the India Office was simply not equipped to deal with the unusual linguistic diversity to be found in Penang, Malacca, and Singapore. During the period of EIC rule (c. 1830-1867) officers were recruited mainly from the Indian army, and the Straits administration was little more than 'a minimum, constabulary government in a poor colony under the tight and grudging control of a distant master'. ${ }^{18}$ Governed as a lesser province of India, it proved difficult to get competent men to serve in the Straits. Yet the India office could not provide Chinese-speaking officers, a need that was becoming more strongly felt as Chinese labour and enterprise streamed into the settlements throughout the 1800s. The socioeconomic repercussions of this large-scale immigration exerted formative pressures on the scope and nature of British rule. Particularly from the 1840s onward, business interests on the peninsula began to push for greater British involvement, in large part due to the immigrant Chinese labour unrest on tin mines in Perak and Selangor.

The Indian Office had, of course, long grappled with the need to secure the 'command of language' crucial to the consolidation of power in India. ${ }^{19}$ In the early 1800 s, EIC officials had taken pains to learn, codify, and teach Indian classical and vernacular languages in colonial institutions established for these purposes in England and India. These institutions included the College of Fort William in Calcutta, established in 1800 and offering instruction in classical Arabic, Persian, and Sanskrit, as well as vernacular languages such as Telugu and Bengali; followed by the college at Haileybury in England, established in 1806 to educate recruits before they went to India; and finally, the College of Fort St George in Madras, specializing in South Indian languages. ${ }^{20}$ But

${ }_{18}$ Robert Heussler, British Rule in Malaya: The Malayan Civil Service and Its Predecessors, 1867-1942 (Westport Conn.: Greenwood Press, 1981), 25.

${ }_{19}$ On the 'command of language', see Cohn, Colonialism and Its Forms of Knowledge, ch. 2.

${ }^{20}$ For an overview of language training in the Indian civil service, see King, One Language, Two Scripts. See also Farina Mir, 'Imperial Policy, Provincial Practices: Colonial Language Policy in Nineteenth-Century India,' Indian Economic \& Social History Review 43, no. 4 (2006), 395-427. 
these specializations were almost irrelevant in the Straits Settlements, where the number of Tamil labourers consistently paled in comparison to migrants from southern China, who, by 1867, made up two-thirds of the entire population of Singapore. 'Indian officers have no opportunity of acquiring experience of the habits or the language of either Malays or Chinese,' Lord Canning remarked, 'and accordingly, when officers are sent to the Straits, they have everything to learn.' Without this special training, he insisted, 'the Indian government cannot do justice to these Settlements'. ${ }^{21}$ There had been much talk, therefore, of borrowing British officers from the Chinese Consular Service. ${ }^{22}$ But even three decades later, as W. E. Maxwell groused to the Royal Colonial Institute, there continued to be a discrepancy between 'the munificence of the Government of India in encouraging the study of native languages and literature' and the relative paucity of such initiatives in the Malay peninsula. ${ }^{23}$

To the problem of Chinese languages, the British devised a bureaucratic solution called the Chinese Protectorate. Conceived as a branch of the Malayan Civil Service (MCS), the Protectorate was established in the Straits Settlements, first in Singapore in 1877 and subsequently Penang in 1881. It spread rapidly through the peninsula over the next forty years: the Perak office opened in Taiping in 1883, and a Selangor office opened in KL in 1890. Singapore and Penang were clearing-houses for indentured immigrant labour, and the early Protectorate might be seen as an immigration centre rationalized on linguistic lines, though it would assume other kinds of tasks, principally the suppression of secret societies, the regulation of women and girls, matters concerning Chinese culture and community, and increasingly from the early twentieth century, the work of policing, censorship, and surveillance. ${ }^{24}$ Across the Straits, the Dutch, also faced with the problem of governing and communicating with their Chinese communities, established the Kantoor voor Chineesche Zaken (Office for Chinese Affairs), though it was set up substantially later than the British Chinese Protectorate, in 1900. Indeed the Kantoor can be understood as a belated formalization of the small but influential channel of Delft and Leiden University-trained sinologist expertise, which had been available to the Dutch colonial administration

${ }^{21}$ Lord Canning, minute of November 1859, quoted in Charles Burton Buckley, An Anecdotal History of Old Times in Singapore (Singapore: Fraser \& Neave, 1902), 765.

${ }^{22}$ Heussler, British Rule in Malaya, 26.

${ }^{23}$ W. E. Maxwell, 'The Malay Peninsula: Its Resources and Prospects' (1891), reprinted in Paul Kratoska, ed. Honourable Intentions: Talks on the British Empire in South-East Asia Delivered At the Royal Colonial Institute, 1874-1928 (Oxford: OUP, 1983).

${ }^{24}$ G. R. Sykes, 'The Chinese Protectorate', TNA, CO 865/47. See also Ng Siew Yoong, 'The Chinese Protectorate in Singapore, 1877-1900,' FSEAH 2, no. 1 (1961), 76. 
since the mid-nineteenth century. ${ }^{25}$ Conversely, the Protectorate was quite clearly conceived as a scheme to meet a worrying shortfall in the British administration's capacity to govern.

The MCS was thus apprised from the very beginning of its linguistic deficiencies. Crucially, however, British officials, from a very early stage, approached the learning of Malay and the many Chinese languages spoken in British Malaya in quite different ways. Their attitudes both reflected and subsequently shaped the quite different natures of colonial governance with regard to the labelling of 'Melayu' and 'Cina' under colonial rule.

\section{Commanding Languages in the Courts of Law}

It would not be until the 1870 s that British cadets were compelled to learn Malay, and it would take another decade before the question of training Chinese-speaking cadets was really addressed. The troubles of the Malayan Babel were apprehended perhaps most clearly at the time by William Pickering, a British missionary who had, prior to his appointment in the Straits in 1872, served for ten years at the Chinese Maritime Customs Service in Hong Kong, where he had picked up Cantonese, Hakka, Hokkien, Teochew, and court Mandarin (guanhua). ${ }^{26}$ Prior to 1872 , schemes had been underway for creating what the colonial secretary referred explicitly to as a 'regular and efficient staff of Chinese interpreters' ${ }^{27}$ Cadets were told directly upon their arrival in the new Crown Colony that what was expected of them above all was language learning, to a standard high enough to serve as interpreters, especially in the courts. Cadets were explicitly encouraged in this period to read law when on home leave, and were promised salary incentives if they passed the bar. ${ }^{28}$ The civil service's Malay language capabilities duly expanded, but until Pickering arrived in 1872, there was no other European official to work as part of the Malayan civil service who was able to speak and write in any Chinese language. The Dutch, on the other hand, had already amassed a relatively strong corps of Dutch interpreters of Chinese by 1864, and had installed an interpreter each in Semarang, Surabaya, Ceribon, Banka, Riau, and Pontianak. The two sinologists

${ }^{25}$ See Leonard Blussé, 'Of Hewers of Wood and Drawers of Water: Leiden University's Early Sinologists (1853-1911), in Leiden Oriental Connections: 1850-1940, ed. Willem Otterspeer (Leiden: Brill, 1989).

${ }^{26}$ William Pickering, Pioneering in Formosa: Recollections of Adventures Among Mandarins, Wreckers, and Head-Hunting Savages (London: Hurst \& Blackett, 1898).

${ }^{27}$ Lt-Governor A. E. H. Anson to Sir M. E. Hicks-Beach, Secretary of State for the Colonies, des. 202, TNA, CO 273/99.

${ }^{28}$ Heussler, British Rule in Malaya. 
who served in Batavia - M. von Faber and Gustav Schlegel - were of especially high quality. Schlegel would go on to be the first professor of Chinese in Leiden University, responsible for training successive generations of Dutch kwekelingen voor de Chineesche taal (Chinese language trainees) bound for colonial service. ${ }^{29}$ The Batavian High Court had thus already been drawing on sinologist expertise for nearly a decade before Pickering even set foot in the Straits and began his work translating official documents into Chinese and interpreting witness testimonies in the law courts.

It was in the courts of law that the problem of language presented itself with special salience - not surprising, since of all the aspects of governance, the negotiation of justice and social conduct is where the most attention to language and its communicative nuances is required, and where the daily business of governing comes most closely into contact with the largest range of society. It was arguably questions of law and arbitration that, for example, obliged the Dutch to ramp up their linguistic expertise in the Indies earlier in the nineteenth century. J. C. Baud, who served in the 1830s as Governor-General of the Dutch East Indies and later as Colonial Secretary, recounted one of the incidents which impelled him to campaign strongly for the establishment of a good language-training program for cadets. Reviewing the pronouncement of a death sentence on three Javanese men, he became convinced that they were found guilty only because the presiding Dutch official had an uncertain grasp of Javanese. He ordered an appeal. Just as the appeal was underway, a similar crime occurred in the same district. The offenders were caught and confessed to both crimes; the three Javanese men, wrongfully accused, narrowly escaped an unjust death. ${ }^{30}$ Pickering had a somewhat different experience. His linguistic abilities allowed him to discover, much to the administration's horror, that local translators ordered to render British proclamations and words into good Chinese had been conducting an extended joke at the expense of their colonial masters. In 'Chinese copies of our own Government proclamations', he reported, "colonial officials were styled "red-haired barbarians". . . the judges, magistrates, barristers and jury were all, by our own paid interpreters, spoken of as "barbarians" or "devils", and the police distinguished by the ironic title of "big dogs". ${ }^{31}$ Despite his facility and great love for his work and learning, Pickering exhibited a typical suite of views of the Chinese communities he worked with, as he highlighted the dangers of colonial

${ }^{29}$ Blussé, 'Early Sinologists,' 335.

${ }^{30}$ C. Fasseur, 'Leiden and Empire,' in Leiden Oriental Connections: 1850-1940, ed. Willem Otterspeer (Leiden: Brill, 1989), 188-89.

${ }^{31}$ Robert Jackson, Pickering: Protector of Chinese (Oxford: OUP, 1966), 17-18. 
linguistic incomprehension. 'The turbulent, conceited and alien masses of the Chinese inhabiting and entering the Straits Settlements and the Native States,' he warned, 'are understood by at most four or five officials of the Colony'. ${ }^{32}$

The difficulties encountered in the execution of law and justice were no doubt compounded by the complexity of the legal system in British Malaya. The small ports, the first footholds of the British onto the peninsula, were legally administered as British territories. The Federated Malay States (FMS) and eventually the Unfederated Malay States (UMS) accepted British residents and British legal arrangements on all matters excepting what was deemed to be Malay religion and custom, which were given administrative and legal representation through the Courts of Kathis and the Courts of Penghulus. The consignment of certain forms of governmental authority to Chinese secret societies also preserved another enclave in the patchwork quilt of legal systems that comprised the early judicial landscape of British Malaya: one as piecemeal and ad hoc as its administration. ${ }^{33}$ 'Magistrates in the early years administered the law according to their own ideas of equity, modified by what they knew of Malay and Chinese custom, and the Indian or the Straits Penal Code.' This, as Isabella Bird observed, resulted in 'a queerly muddled system of law ... Muhammadan law existing alongside of fragments of English criminal law, the Residents' notions of equity overriding all else. ${ }^{34}$

Despite this complexity, the British insisted on executing liberal justice according to imported legal protocols. The convoluted language of British law was not easily translated, even had there been competent interpreters. Throughout the 1890 s, as British rule formalized in Perak, Selangor, and Negri Sembilan, British residents in these newly federated Malay States began to insist that criminal courts were to follow the procedural details of the English Court of Petty Sessions to the letter. But officials most intimately connected with the execution of justice in the colony among Chinese populations, such as Nicholas Dennys of the Chinese Protectorate, frequently reached the conclusion that European ideals and 'useless technicalities' of the rule of law could not be implemented in the Straits Settlements. ${ }^{35}$ The practices of British law on the

${ }^{32}$ Letter from Protector to Colonial Secretary, 10 July 1888, in 'Suppression of Chinese Secret Societies', TNA, CO 273/154.

33 On the legal challenges of these secret societies, see Wilfred Blythe, The Impact of Chinese Secret Societies in Malaya: A Historical Study (London: OUP, 1969).

${ }^{34}$ See Michael Peletz, Islamic Modern: Religious Courts and Cultural Politics in Malaysia (Princeton, NJ: Princeton University Press, 2002), 48-49.

35 Jean Elizabeth DeBernardi, Penang: Rites of Belonging in a Malaysian Chinese Community (Singapore: NUS Press, 2009), 73. See also Sir Frederick Weld, 'The Straits Settlements and British Malaya' (1884) reprinted in Kratoska, 'Honourable Intentions,' 43-90. 
ground thus occasionally bordered on farce. One can find many examples of these moments of untranslatability in the recollections and memoirs of colonial officials who had close dealings with the courts. W. B. Shelley's story is exemplary, though not exceptional.

Shelley was a European magistrate who served as a Registrar for a judge presiding over a temporary Court of Assize in Seremban circa 1905. The Assizes, an institutional import from the English justice system, were periodic criminal courts held by rotation in large towns on the peninsula, convened to hear more serious cases which could not be dealt with by magistrates. Assizes for criminal and civil cases were held approximately eleven times a year in Seremban, six times a year in Taiping, four times a year in Bentong, and three times a year in Kuantan. ${ }^{36}$ The first case for that year's Seremban assize was a murder trial; the judge, a newcomer to the colony, his solemn gravitas perhaps slightly offset by the bedraggled wig under which he sweltered in the tropical heat. When the Court opened, the Deputy Public Prosecutor handed Shelley the charge in English, which contained details of the offence but not of how the accused intended to plea. Shelley read out the charge, and before handing it to the Chinese Interpreter to translate to the accused, added: 'Do you plead guilty or not guilty?' The judge at once intervened. 'No, no, Mr Registrar. You must not put that to the accused.' The proper procedure as prescribed by the Code of Procedure, he explained, was to ask the accused whether he pled guilty or whether he claimed to be tried. The judge then turned and addressed the Chinese Interpreter sternly: 'Now, Mr Interpreter, you must explain very carefully to the accused that he may plead guilty or claim to be tried. You must not ask him whether he pleads not guilty. A plea of not guilty was purposely excluded by the framers of the Code. By claiming to be tried, the accused, although he may know he is guilty, says in effect that the prosecution has got to prove that he is guilty. You fully understand?'

The Chinese interpreter nodded vigorously: 'Very good, my Lord'. He promptly turned to the accused (as Shelley recounts), translated the charge into a rapid stream of Chinese, and then asked, by way of concluding: 'Lu salah - bo?' (You guilty - or not?) The accused replied indignantly: 'Bo salah!' (Not guilty!) Calmly, the interpreter turned back to the Judge and reported: 'He claims to be tried, my Lord'. ${ }^{37}$

Shelley, recalling this some sixty years later, reflected somewhat wryly on the sheer impossibility of conveying 'in Chinese to an uneducated coolie the subtle distinction between "Not Guilty" and "claim to be tried"'.

${ }^{36}$ Great Britain, Parliament, House of Commons, Papers by Command, Vol. 46 (London: HMSO, 1916), 20-23.

37 Account summarised and paraphrased from W. B. Shelley, 'The Court Interpreter', UL, RCMS 103/4/29. 
The absurdity of this arose in part from the incongruity of English law in a polyglot colony: this distinction, between 'not guilty' and 'claim to be tried' - a fine one even by lay English-speaking standards - shaded into insensibility in a situation in which witness testimony, court hearings, and judgments were funnelled back and forth between judge, prosecutor, and defendant through not just two but often three or more languages. Even Shelley's Chinese interpreter would have been something of a thankful rarity in colonial courts just a few decades earlier, in Pickering's time: for then, Chinese translators in courts frequently spoke Malay but almost no English; and judges frequently spoke Malay but almost never any of the Chinese languages. Indeed, the plaintiff in the preceding account is speaking a Hokkien-Malay creole, and uses the Malay word salah (guilty, wrong) instead of a Chinese word. Communications about these complex legal distinctions thus wended their way back and forth between Chinese languages into Malay, and then from Malay into English. 'The great drawback of having the evidence filtered through the mouths of two interpreters,' Chief Justice Sir Thomas Sidgreaves wrote dryly, 'is inevitable'. ${ }^{38}$

Putting aside these technical absurdities of British legal incursions into Malaya, concerns about the linguistic incompetence of the colonial state also presented themselves, perhaps most pressingly, as the 'want' of interpreters, especially in the Judges' and Magistrates' Courts as well as in the police force, and above all, in Chinese languages. 'I know of no subject in connection with the interests of the Colony, which calls more urgently for early attention,' the Acting Governor of the Straits Settlements wrote in June 1879, 'than the maintenance of the purity of the course of Justice, by means of honest and trustworthy interpreters'. ${ }^{39}$ The key words here were honest and trustworthy. The great difficulty with Chinese interpretation, Sir Thomas Sidgreaves insisted,

... arises not so much from a want of Knowledge on the part of the Interpreter as from the utter want of check upon their interpretation. The Malay Interpreters and to a certain extent the Tamil Interpreters can always be kept in check by the fact that there are persons in Court who are familiar with those languages, and who would readily detect any gross inaccuracy of or wilful perversion by the Interpreters. The Chinese Interpreter speaking to the witnesses in a language which with its many dialects may be said to be an unknown tongue as far as the rest of the Court are concerned, acts practically without check or suppression, and the Knowledge of this power forms of itself a danger, leading as it easily may

38 Thomas Sidgreaves to Cecil Clementi Smith, enclosure in des. 202, 10 June 1879, TNA, CO 273/99.

${ }^{39} \mathrm{Lt}-\mathrm{Colonel}$ Anson to Secretary of State for the Colonies, des. 202, 10 June 1879, TNA, CO 273/99. 
to inaccuracy, slovenliness and a tendency to save time when a stupid witness is in the bar by inventing or suggesting answers for him. ${ }^{40}$

The Chinese interpreters were by and large, it was charged, 'men of poor education and of little or no social standing'; yet they had been placed in 'a most responsible position, and have carried on their duties almost unchecked, owing to the very few persons connected with the Courts who have had even a slight knowledge of Chinese'. ${ }^{41}$

There were, of course, educated Chinese-speaking individuals available to perform the work of court interpretation. But in the eyes of colonial officials, there were few with whom the government was capable of communicating. Pickering and Cecil Smith submitted a report from a survey they conducted of Chinese interpreters presently employed in the Straits Settlement courts. The almost universal lack of English-language competency among the Chinese interpreters, they concluded, was the nub of the problem. For example, one Tan-Kwan-cheat, a Hakka interpreter serving in the Singapore Court of Requests, was judged to speak excellent Malay, Hokkien, Teochew, Cantonese, and Hakka - by most measures surely the gold standard of interpreter in a polyglot colony. His singular deficiency, however, was that he spoke no English at all, and thus, 'owing to the very imperfect knowledge the two superintendents of Police have of the Malay language, this man has become useless'. ${ }^{42}$

Their survey also demonstrates a keen concern with the character of the interpreters, which were judged to be just as important as their actual translating abilities. In fact, an interpreter's knowledge of English correlated strongly with positive assessments of their characters. Chu-ah-yan, a Hakka who served in the Supreme Court in Singapore, spoke good English and was deemed to have 'a very good character and deserves a higher rate of salary'; Yup-soon-guan, the interpreter in the service of the Malaccan Superintendent of Police, spoke good English and was 'the best of all interpreters' and 'a very respectable man'. On the other hand, Oh Kim See and Oh Koon Choon, both of whom spoke terrible English, were of bad reputation, stubborn and proud, as well as being 'bores', respectively, to the sitting magistrates of Province Wellesley and Penang. ${ }^{43}$ The recommendation at which Pickering and Cecil Smith

40 Thomas Sidgreaves to Cecil Clementi Smith, enclosure in des. 202, 10 June 1879, TNA CO 273/99.

41 Anson to Secretary of State for the Colonies, in des. 202, 10 June 1879, TNA CO 273/99.

42 'List of Chinese Interpreters employed in the Courts, Straits Settlements', enclosure no. 1 to Report by William Pickering and Cecil C. Smith, 3 May 1879, des. 202, TNA, CO 273/99. Hereafter Pickering-Smith Report, 1879.

43 Pickering-Smith Report, 1879. 
arrived was to simply retire all Chinese interpreters who could not speak English. In place, they suggested a system of employment which would class new interpreters according to their proficiency in both English and Chinese, and proposed a new and higher scale of remuneration, since it was generally agreed that 'competent and trustworthy men' could not possibly be engaged without 'additional prospects' - that is to say, good salaries.

The reliance on these interpreters for almost every aspect of colonial interaction with those whom they wished to govern reveals, as many other colonial situations also do, the brittleness and fragility of colonial rule. The question of language reliance is a curiously invisible, often unremarked feature of colonial rule. Yet it constitutes one iteration of the more general dialectic of fear and dependence that characterizes the colonizer-colonized relationship. In its most raw form, this coexistence of distrust and dependence is often clearest in economic relationships, perhaps nowhere more sharply than in the urban settlements created, literally from scratch, by Europeans: Batavia and Manila. In these motley commercial enclaves, 'the scales of interdependence between Europeans and Chinese tipped under the weight of increasing influence wielded by the Chinese' ${ }^{44}$ From the very beginning of Spanish rule in the Philippines, attitudes to Minnan Chinese merchant communities in Manila veered almost schizophrenically between deep admiration and profound distrust and fear. By the seventeenth century, Spanish material dependence on Chinese trade and small enterprise to provide basic necessities and foodstuffs for the fledgling colony was almost complete - as one governor admitted in 1628: 'There is no Spaniard, secular or religious, who obtains his food, clothing or shoes, except through the Chinese. ${ }^{35}$ As the wellbeing of the Philippine economy became thoroughly enmeshed with the activities of sojourning Chinese communities, dependency and admiration was punctuated with sudden acts of rejection and extreme violence - namely, government-sanctioned massacres throughout the seventeenth century. And just as each massacre rained destruction upon the Parían and all but decimated its resident Chinese populations, so, too, would each massacre be followed, after a brief respite, by Spanish contrition and the invitation of Chinese traders, labourers, and artisans back into Manila, to rebuild the Parían from the ashes of destruction and

${ }^{44}$ Leonard Blussé, Strange Company: Chinese Settlers, Mestizo Women and the Dutch in VOC Batavia (Dordrecht-Holland: Foris Publications, 1986), 78.

${ }^{45}$ Evelyn Hu-DeHart, 'Integration and Exclusion: The Chinese in Multiracial Latin America and the Caribbean,' in Routledge Handbook of the Chinese Diaspora, ed. Tan Chee Beng (London: Routledge, 2013), 92. 
revive trade - at least until the next state campaign to cut them down again. ${ }^{46}$

Questions of language in British Malaya would never provoke such overt violence; and yet the challenges they posed - how to balance dependence and distrust - was of a piece. If the problem had really just been about the need for interpreters, it would hardly have mattered who these interpreters were, as long as they could translate. But, of course, as Ann Stoler has put it of analogous situations in the Dutch East Indies, 'At issue was obviously not whether civil servants knew local languages, but how those languages were learned and used and whether that knowledge was appropriately classified and controlled'. ${ }^{47}$

Thus, judgments of control and trust often aligned with race. There was no real reason, for example, for why the Dutch should not have appointed Chinese officers to the Kantoor, but the fact remained that they did not. The British would employ native Chinese if they were of 'good character', but Eurasians were preferable, for to the race-inflected paranoia of the late Victorian colonial mind they were more reliable for being closer to whiteness. In these tortured debates about rectifying the colonial state's impossible deficiencies in interpretation, Eurasians were the perfect compromise between economy and reliability. 'It is obvious,' the Secretary of State for the Colonies wrote in 1878, 'that if Eurasians can learn to interpret Chinese and English with sufficient facility for the work of the courts under the supervision of the head of the Chinese Department, there would not be the same necessity for a costly staff of European Interpreters, as was once contemplated'. Much hope was thus placed in a Raffles Institution class in Hokkien, which had been established in 1864, and under whose auspices a very successful scholarship scheme designed to encourage the study of Hokkien by local-born Europeans and Eurasians was instituted in $1878 .^{48}$

But these trustworthy Eurasians were few and far between, and there were certainly not enough of them to staff an entire administration, even if they could all have learned Hokkien to a reasonable standard. What was more desirable, Pickering explained in a later report, was rather 'a staff of officials who can keep a check on their subordinates.' Pickering, in other words, advocated the creation of a supervisory class. The only

46 State-sponsored massacres of Chinese populations in Manila took place in 1603, 1639, 1662, 1686, 1762, and 1819: on this, see Blussé, Strange Company, ch. 5.

47 Ann Stoler, Race and the Education of Desire: Foucault's History of Sexuality and the Colonial Order of Things (Durham, NC: Duke University Press, 1995), 108.

48 On this, see Michelle T. King, 'Replicating the Colonial Expert: The Problem of Translation in the Late Nineteenth-Century Straits Settlements,' Social History 34, no. 4 (2009), 438-40. 
way to govern the Chinese, he insisted, was to train a staff of trustworthy European officials in Chinese language and 'mode of thought' to better 'supervise and control them' ${ }^{49}$ The question of locating or training reliable local interpreters, whether Eurasian or Chinese, was thus perceived to be a fundamentally different one from the question of teaching Europeans how to speak Chinese. The former ought not to be 'mixed up' with the latter, one official wrote, 'for the only connection between the two seems to be that if all our civil servants in these colonies knew Chinese thoroughly, interpreters might be no longer required'. This was a scenario which seemed to many a distant and impractical dream. ${ }^{50}$ In service of this improbable yet attractive ideal, the solution which the colonial state began to grope towards was not to train more locals or Eurasians to interpret for the government, but instead to find some way to produce more Europeans who spoke Chinese languages. The Asiatic Babel, colonial officials were beginning to conclude, was most safely tamed by European tamers.

The paternalism implicit in this is a familiar theme of imperial governance. The desire for Chinese-speaking Europeans was crucial for maintaining European prestige and capacity to govern: as Pickering put it, it was to counter the 'grave abuses which now exist in many of our departments owing to the almost uncontrolled power of the Chinese employees', and to 'do away with a state of things which must in native eyes reflect most injuriously upon any Government which professes itself to be superior to that of the Chinese themselves. ${ }^{51}$ Yet the question of training European cadets in necessary languages brought an entirely different set of dangers. It was not only the dependence on, and want of, reliable native interpreters which exposed the fragility of colonial rule. The problem of Chinese language learning exposed the terrible untrustworthiness not only of the governed, but of the governors themselves.

\section{Who Commands the Language Commanders?}

Schemes to produce Chinese-speaking Europeans were beset on all sides by a seemingly endless potential for vice. Pickering believed firmly in the raison d'etre for the creation of a Chinese-speaking technocracy within the colonial state, which was that the Chinese communities needed a Confucian 'virtuous prince', by which he meant a government 'just and

49 DeBernardi, Rites of Belonging, 73.

${ }^{50}$ Minute, in des. 36, 18 March 1878, TNA CO 273/93.

51 Report by William Pickering and Alexander Grant to the Colonial Secretary, 30 July 1880, enclosure to des. 178, 'Report on Progress of Cadets Learning Chinese,' TNA, CO 273/104. Hereafter Pickering-Grant Report, 1880. 
firm' which would not allow 'the liberty of its subjects to degenerate into licentiousness' ${ }^{52}$ Yet when it came to language learning, it was in fact the government itself which was just as threatened by the danger of degeneration. From the internal debates about the measures attempted to ensure that Chinese was more widely spoken throughout the civil service, what emerges is a picture of the deep-seated fear concerning the maintenance of the hierarchies and position of the colonial state itself: a fear which, it turned out, its deficiencies of language was very good at exposing. The problems of language threatened to uproot the secure paternalism of imperial command. Two incidents, punctuating the long and putatively successful history of the Chinese Protectorate, will serve to illustrate this.

The first is the case of Henry Cooper and Francis Powell. At around the same time that local-born Europeans and Eurasians were being cajoled into Hokkien classes, the first two English cadets were also being groomed for Hokkien study. From their first arrival in the Straits in 1878, Cooper and Powell undertook Hokkien study in Singapore. The results, after a year and a half, were not promising. William Pickering and fellow Presbyterian sinologist Alexander Grant, who jointly examined them in 1880, reported that the cadets had made much progress on the study of the written language, through textbooks of orientalist language study and Chinese classics such those by James Legge, but had made lamentably little progress on the 'Hokkien colloquial'. A year and a half later, Cooper was only just able to 'catch the gist of a short and single statement', whereas Powell, although somewhat more accomplished, was still nonetheless only able to understand a Hokkien speaker 'who will talk down to his standard'. Surveying what the two cadets had accomplished in this period of time, Pickering and Grant remarked, in rather damning fashion, that 'we cannot overlook the fact that the same amount of knowledge might have been gained in England'. ${ }^{53}$ Enclosing this report in a memo to the Colonial Office, Frederick Weld, observing irritably that 'it is difficult to believe that the Cadets have applied themselves as much as they ought to in their studies', begged the Secretary of State for the Colonies to consider seriously Pickering and Grant's recommendation that 'we cannot hold out any hope of further improvement unless the Cadets be sent to China for at least one year'. ${ }^{54}$

The question of where best to train the cadets had, in fact, been raised several times prior to Cooper and Powell's dispatch to Singapore: whether

52 William Pickering, 'The Chinese in the Straits of Malacca,' Fraser's Magazine 14 (1876), 443.

53 Pickering-Grant Report, 1880.

${ }^{54}$ Frederick Weld to the Earl of Kimberly, des. 175, TNA CO 273/104. 
they ought to be trained initially in Britain (and if so, whether at Oxford, or King's College, and whether they ought to also be subjected to some amount of 'office work' by way of preparation), or whether they might be trained in the Straits or in China. One important advantage of training them in England before sending them to the colony was, of course, economy: as one official remarked, 'if Chinese can be learnt satisfactorily of a European teacher in this country [i.e., England] at lectures costing 3 guineas a term each pupil, it would be far cheaper for Govt Colonies to pay their cadet here for a year or two $£ 100$ a year $\&$ these fees, than to pay them $\$ 1200$ in China \& a European teacher $£ 300$ a year. ${ }^{55}$ Another advantage was that in England cadets might be taught the language 'scientifically' - that is to say, with the attention to grammar, structure, and 'rudiments' of the written form of 'court' Chinese, the nuances of which could be conveyed only by English professors such as James Legge (1815-1897) at Oxford, or Robert Douglas at King's College London, for it was 'a task for which the ordinary Chinese teachers are quite incompetent'. ${ }^{56}$ This was the late Victorian standard of language-learning, privileging writing over orality and abstracted structure over situational absorption. But Pickering, who had learned his languages differently, suggested that this was less of an advantage as it might seem, since the 'scientific' approach to learning the written language appeared to be no guarantee that cadets would be able to deal with its orality in day-to-day colloquial form. 'What is wanted,' one official wrote, in reference to Chinese languages, 'is the vernacular, not scientific scholarship in a language which for literary purposes is as useless as Welsh or Gaelic'. ${ }^{57}$ Pickering, for his part, was generally disposed to dismiss 'university men' for language learning purposes as being 'too grand'. Influenced by his missionary and non-traditional educational background, he was a consistent advocate of the notion that the only way to learn how to speak Chinese languages was to go to China. ${ }^{58}$

A proposal had in fact been mooted earlier, in 1875 under William Jervois, that cadets ought to be trained in China. It seemed a logical solution, but the idea had been quickly abandoned 'as we could derive no system under which the Cadets could be properly supervised during their stay at the Chinese Ports. ${ }^{59}$ This is key: one finds in the correspondence on this matter that repeatedly, there was resistance to the prospect of sending cadets to China on the grounds that they could not

55 Minute, 5 December 1880, des. 198, TNA CO 273/104.

${ }^{56}$ Minute, 1 June 1878, des. 366, TNA CO 273/93.

57 Minute, 5 December 1880, des. 198, TNA CO 273/104.

58 Despatch from William Jervois to the Right Honourable Earl of Carnavon, Secretary of State for the Colonies, 15 August 1875, des. 234, TNA CO 273/81.

59 Minute 12 March 1878, des. 36, TNA CO 273/93. 
be adequately supervised. Such an arrangement could hardly be considered revolutionary, as Frederick Weld pointed out to the Secretary of State for the Colonies, since the Dutch had been sending their cadets to Amoy to learn Hokkien since at least $1857 .{ }^{60}$ Yet it appears to have taken Weld's rather caustic report of Powell and Cooper's progress (or lack thereof) in 1880 to finally push through the sense that, as the assistant under-secretary in the Colonial Office C. P. Lucas put it, 'it is a farce their pretending to learn Chinese in the Straits any longer' ${ }^{61}$ At this, the Secretary of State for the Colonies gave in, albeit somewhat grudgingly - 'Cadets may go to China,' the Earl of Kimberly decreed, for a period 'not exceeding a year', and insisted once again that cadets should receive 'adequate supervision' during their absence. It was decided that Powell and Cooper would be sent to Amoy for a period of six months twelve if subsequently thought advisable - to be under the supervision of Herbert Giles, the British Consul at Amoy. They would, Weld assured the Colonial Office, be sent back to Singapore at the slightest sign of bad report.

The exchange smacked of a kind of overbearing paternalism: the problem of language learning, it seemed, exposed a different kind of fragility closer to the heart of the colonial state. When it came to meeting the most central deficiency of the colonial state in a polyglot society, the infamous 'colonial paternalism' appeared to apply equally to the colonized untrustworthy without as to the colonizing untrustworthy within. Here, the problem of supervision was literally couched in terms of age. The problem was simply that in the administration, cadets were thought too young to be trusted to act sensibly. This is worth noting. Youthfulness was not perceived as a threat in any other functionings of colonial governance; the colonial civil service was routinely populated by fresh-faced university graduates in their early 20s. In 1912, for example, a member of the Royal Commission on the Civil Service put a question directly to the Permanent Undersecretary at the Colonial Office, Sir John Anderson: 'Is a young man of 23 who comes fresh from the university, who has never had any work to do, and no business experience whatever, competent at once to advise the secretary of state on matters of policy?' Anderson replied with characteristic economy: 'He is allowed to try. ${ }^{62}$ Indeed, in a despatch to the Colonial Office in 1878, William Robinson forwarded the suggestion that because Chinese languages appeared to take on average

${ }^{60}$ On these early Dutch cadets, see Blussé, 'Early Sinologists,' 335.

${ }^{61}$ Minute, n.d., des. 178, TNA CO 273/104/

${ }^{62}$ Sir John Anderson's Testimony to the Royal Commission on the Civil Service, 17 May 1912, in Great Britain, Parliamentary Papers, 1912-13 (Cmd. 6535), 134. 
twice as long to learn as Malay, cadets should be given special dispensation to 'come out' to the Straits Settlements at an earlier age than most cadets tended to, and no later than the age of 20. Frederick Weld agreed, expressing doubts that there could be enough incentive for cadets who were learning Chinese to spend so much longer than their age peers 'in statu pupillari' (up to age 28, it was estimated), and in such a 'tropical and enervating climate', before they could qualify as full-pay civil servants. ${ }^{63}$

But others demurred. One wrote: 'I differ from Sir W. Robinson as to sending out young lads of twenty - a few more years spent in [England] will give them physical strength \& should also strengthen their moral fibre. ${ }^{64}$ 'I am not in favour of sending out cadets too young,' another wrote, 'it is not easy for Govt. to supervise boys' ${ }^{65}$ Both Cooper and Powell, as it turned out, were two years older than either Weld or Robinson would have liked; still, the dissenters who had no faith in the young were, in the case of Powell and Cooper, apparently proven right. Moral fibre in particular was, it seems, what was needed, and lacking: the sheer difficulties of Chinese language learning appeared to have brought out an unforgivable and embarrassing indolence in a class of men who, as Pickering frequently reminded his fellow officials, were supposed to represent a government which 'professes itself to be superior to that of the Chinese themselves'. ${ }^{66}$

And alarmingly, as it turned out, the vices of language learning would not be restricted to mere indolence. Shortly after the cadets were finally sent to Amoy in 1881, a scandal erupted around Cooper, the less accomplished of the two, concerning several counts of drunken assault, one of which involved a Cantonese woman whom Cooper had allegedly been 'keeping' and had, one night, staggered home drunk and proceeded to beat her. Cooper was sent home to England in great disgrace, and the Colonial Office subsequently received a profuse apology from his father. Powell, though surviving his time in Amoy more or less morally unscathed, eventually succumbed to what the Colonial Office referred to rather blandly as 'intemperance': after several years of otherwise quite successful service in the Chinese Protectorates in both Singapore and Penang, he retired early on account of poor health, returned to England in 1893 and quickly degenerated into alcoholism, rent-default and penury. ${ }^{67}$ Thus was the inglorious fate of the first experiment to raise a class of European sinologues.

${ }^{63}$ Minute, 5 December 1880, des. 198, TNA CO 273/104.

${ }^{64}$ Minute, 12 March 1878, des. 36, TNA CO 273/93.

${ }^{65}$ Minute, 26 February 1876, des. 234, TNA CO 273/81.

${ }^{66}$ Pickering-Grant Report.

${ }^{67}$ For this story, see King, 'Replicating the Colonial Expert,' 441-42. 
The second flashpoint in the travails of taming Babel occurred under the governorship of Cecil Clementi (1875-1947) in the early 1930s. By this point, the Chinese Protectorate had come quite a long way from its early ad hoc days; it had become, as Protectorate officer Wilfred Blythe later put it, 'the finger on the pulse of the Chinese community' ${ }^{68}$ In parallel with this, the colonial state's general language learning practices had also become significantly more systematic. Like a rite of passage, all new cadets were put through a process of initiation into cadetship. Once they had passed the written civil service examinations, all cadets did a three-month course in Malay at the School of Oriental Studies in London, conducted by Charles Otto Blagden, a retired member of the MCS and a 'keen Malay man' who had published prolifically on questions of Malay linguistics. ${ }^{69}$ During this course, cadets would be given a 'tone test' and 'checked for musicality', to see if they would be capable of learning a Chinese language. It was at this point that new recruits were presented with a major question, in many respects the determining factor of their service in Malaya, though at the time many of them would not be aware of the import of this choice. Which of the three streams would they be assigned to: Malay, Chinese, or Indian languages? For each of these now had defined, almost stereotyped trajectories. Malay was seen to offer the most varied and interesting work, and the best chance of promotion; Chinese languages were the most difficult; the Indian languages the most confining of the three. Few Chinese-streamed officers became so by their own choice; it was widely considered that their future prospects were diminished by their being selected to learn Chinese. For by now, the Protectorate, although doing good work, had acquired a reputation as something of a dead end: a cave of specialists generally excluded from taking direct part in the political planning and administration of the country, which was felt to be the province of the Malay-language cadets. Those who were corralled into Chinese-language service were haunted their whole professional lives by the most outlandish stereotypes. 'I have a suspicion that at times cadets who appeared to be least socially acceptable were posted to Chinese,' Blythe intimated. ${ }^{70}$ Yet it was those who had survived the trenches of language learning who often emerged into the Protectorate with the fiercest sense of pride, and were quite happy

${ }^{68}$ W. L. Blythe, 'The Malayan Civil Service', 26 November 1970, correspondence to Robert W. Heussler, Rhodes House Library (RHL) Mss. Brit. Emp. s. 480 (henceforth Heussler Papers), Box 9, File 3.

${ }^{69}$ The following account synthesized from the correspondence notes to RobertW. Heussler by R. N. Broome (Heussler Papers, Box 10, File 1) and J. M. Barron (Heussler Papers, Box 9, File 1).

${ }^{70}$ Blythe, 'The Malayan Civil Service'. 
to help nourish the myths. 'The feeling of being "out on a limb",' R. N. Broome later recalled, "was probably one of the causes of the exceptional "esprit-de-corps" that existed among the Taijins. While the Malay-speakers regarded us as a collection of madmen, we thought of ourselves as an 'elite'."71

By the time Clementi took office in 1930, therefore, cadets were being systematically sent to both Amoy and Canton for two years to learn Hokkien and Cantonese, respectively. ${ }^{72}$ Clementi had been educated at London and Oxford, qualifying as a cadet in the Foreign Office in Hong Kong in 1899 and working his way up to Colonial Secretary in Ceylon and then governor of Hong Kong between 1925 to 1930. A skilled colonial administrator, he was fluent in guanhua, Hokkien, Cantonese, and other dialects, and he was widely read in Chinese classics. But he had a nostalgic, essentialized notion of China, a China of classic Confucian patterns, whose language and literature were best approached in scholarly fashion away from the noisy rabble of labouring, striking, truculent Chinese communities over which he presided with an air of a long-suffering mandarin. Clementi also held a vision of China which always fell short in his dealings with real Chinese communities in Hong Kong and then in Malaya. He disliked modern Chinese nationalism, scornful of those who partook of it. ${ }^{73}$ As Charles Corry later recalled of him, 'For a man who was a distinguished Chinese scholar and knew so much of the interior of that vast country, he was, in my opinion, curiously unsympathetic to the Chinese.... ${ }^{74}$

As Governor of Hong Kong, Clementi had been deeply involved in questions concerning education, but again, from a deeply conservative perspective. China in the 1920 s was a restless place, filled with new political ideas and an unprecedented surge of popular will to enact these in politics and society. Clementi's conservatism was nurtured in this environment of political uncertainty. In 1927, addressing a committee of senior Chinese literati, he asked them to help him develop a curriculum based on orthodox Confucianism, which would emphasize social hierarchy and subservience to patriarchal hierarchy, in an appeal to 'the cultural tradition of the native people to help safeguard foreign rule against

71 Broome, 'Notes on the Chinese Protectorate', Heussler Papers, Box 10, File 1.

72 Though more were now being sent to Canton than Amoy, which some considered to be a great mistake, since the Hokkiens greatly outnumbered Cantonese. For the objections, see Broome, 'Notes on the Chinese Protectorate'.

73 Clementi as characterized by Yong Ching Fatt and R. B. McKenna, The Kuomintang Movement in British Malaya, 1912-1949 (Singapore: NUS Press, 1990), 135-36.

74 Impression of Clementi by Charles Corry, Letter to Heussler, 29 April 1974, Heussler Papers, Box 11, File 1. 
the growth of nationalistic feelings among the younger generation' ${ }^{75}$ These plans led to the establishment of a new Chinese Department at Hong Kong University - an unprecedented move for HKU, which had been thoroughly modelled on British universities. In this, Clementi was supported in his conservative pedagogy by fellow sinologue and missionary H. G. Wells, with whom Clementi appears to have had a warm friendship, and who shared Clementi's belief in the virtues of restoring the study of China, not from the vantage of its turbulent and unruly present, but from the very beginnings of its early literature 'for instance as represented in the eight diagrams and the sixty figures of the Book of Changes'. ${ }^{76}$

Clementi continued to be involved with these plans, even after leaving his HKU post. Not long after he settled into the Straits Settlements, he wrote to Wells: 'There is nothing I regretted more in my departure from Hong Kong than the fact that I had to leave the work in connection with the Chinese School of the Hong Kong University and the Chinese Faculty at the University . . barely just begun'. Clementi assured Wells that although 'I am afraid that from Malaya I cannot do much to help ... I shall certainly try to interest the local Chinese and to secure funds from Malaya [for it]'. He also said he had been considering sending Malayan cadets and police probationers who were required to learn Cantonese to the new university, and had said as much to William Hornell, the Vice Chancellor of HKU, earlier that year. 'Will you please remind him of this,' Clementi asked Wells, 'and ask him to let me have his views in due course? ${ }^{77}$

Two months later, Hornell did write to Clementi concerning the Cantonese class at the new Chinese department in HKU. But it was not, perhaps, the letter Clementi was expecting. 'When I got back to Hong Kong in March,' Hornell wrote, 'I found complete chaos reigning'. The three police probationers who had been sent from the SS and FMS to study Cantonese under Wells and a Cantonese teacher, Sung Hok Pang, had been deemed utterly reprobate: in particular two of them, Mr Anderson and the appropriately named Mr Silley. Since their arrival in November 1929, Hornell said, 'they did not make the slightest attempt to attend the classes', nor had they made any attempt to even make enquiries into starting classes until early January. Even since then, $\mathrm{Mr}$ Anderson had apparently attended just three out of 23 classes

${ }^{75}$ Bernard Hung-Kay Luk, 'Chinese Culture in the Hong Kong Curriculum: Heritage and Colonialism,' Comparative Education Review 35, no. 4 (1991), 660.

${ }^{76}$ Letter from H. G. Wells to Cecil Clementi, 5 March 1930, RHL Mss. Ind. Ocn. s. 352 (henceforth 'Clementi Papers'), Box 26, File 4.

${ }_{77}$ Letter from Clementi to Wells, 20 March 1930, Clementi Papers, Box 26, File 4. 
in the whole of February. They were, in addition, spending a 'large amount' on entertainment and drink, and were also behaving 'exceedingly badly at the University Union', which none of them had actually joined as dues-paying members, but at which they continued to 'monopolize tables in the refreshment room', accompanied, it seemed, by their Chinese teachers. All this bad behaviour was, Hornell explained, most unsatisfactory, since 'when these young men from the SS and FMS fail hopelessly, as some of them I imagine are bound to do, the university would get the blame'.

That they were young men was, it seemed, again the nub of the problem. Police probationers in particular, he said, 'were a good deal younger than the cadets and far more irresponsible', which was a shame, because in many other respects, the Cantonese class appeared to be functioning quite well apart from 'the utter irresponsibility of such young men as Messrs. Silley and Anderson' ${ }^{78}$ Clementi had all these officials reprimanded with strongly worded private letters, but took no more serious action than that, writing to Hornell that 'I have taken up the matter in this way in order to give these young men a chance of turning over a new leaf, but if they do not do so, I shall come down upon them with great severity'. ${ }^{79}$ Clementi, the paternalist mandarin, found himself in the position of having to dispense discipline at once to his Chinese subjects as well as to the Chinese-language cadets of the British colonial service.

The youthfulness of European civil service cadets, often overlooked or perceived as unproblematic in other areas of colonial governance, seemed to assume special significance, and raise special alarm, in the context of Chinese language-learning. Age as a category of analysis, some scholars are beginning to insist, has for too long remained perhaps as invisible as gender once was. ${ }^{80}$ The tensions which language learning opened up within the colonial state might be amenable to such analysis. Considerations of their lack of linguistic expertise led the colonial state inexorably to the need to create European sinologues, and this would persist right into the postwar Emergency (a theme we will pick up again in Chapter 4). But the search for European sinologues showed up age-inflected tensions of empire. In the attempt to secure the command of language, the colonial state came face to face with a new need: to ensure that their command over those who would command the language stayed firm enough to maintain their already-thin semblance of

${ }^{78}$ Letter from William Hornell to Cecil Clementi, 19 May 1930, Clementi Papers, Box 27, File 2.

${ }^{79}$ Letter from Clementi to Hornell, 27 May 1930, Clementi Papers, Box 27, File 2.

${ }^{80}$ For the classic statement, see Laura L. Lovett, 'Age: A Useful Category of Historical Analysis,' Fournal of the History of Childhood and Youth 1, no. 1 (2008). 
power and control over their polyglot colony. When it came to the management of the colonial state's language skills, it seemed that the constituents of the state needed as much disciplining as the subjects over whom they governed.

\section{Deficiencies Abound}

Even the two or so years spent struggling through the language and achieving a generally high standard in it would prove in due course to be insufficient for doing civil service work in Malaya. 'Back on the job, we still had to work with interpreters,' Broome recalls, 'because of the rich variety of dialects in Malaya' ${ }^{81}$ Each officer could only realistically learn one of the Chinese languages; and yet, in Malaya, the work they would do at the Chinese Protectorate would bring them into contact with Chinese-language speakers from all possible backgrounds. In addition, as some officers complained, there were many important differences within the languages themselves. 'In the Singapore Protectorate no one could carry on a day's work (except through an interpreter) unless conversant in some degree with at least 4 dialects of Chinese, each differing from the other as much as English from German or Spanish from Italian... ${ }^{82}$ Tom Cromwell, who entered the Chinese stream of the MCS at around the same time as Broome, was sent to Amoy to learn Hokkien, while Broome was sent to Canton for Cantonese. Cromwell came to the conclusion that the Hokkien he was learning so painstakingly at the Singapore Mess in Kulangsu, Amoy, was not after all wholly applicable to the Malayan circumstances. 'The majority of overseas Chinese Hokiens in British Malaya do not speak the exact dialect of Amoy proper,' he complained to A. B. Jordan in 1934. 'Singapore Hokien [sic] is, I take it, such a variation and under the circumstances cannot be acquired perfectly in Amoy, though such modifications as it has undergone may be readily understood and mastered later by one who has formerly concentrated more particularly on the Amoy dialect. ${ }^{93}$

Singapore Cantonese, too, was not exactly the same as its Hong Kong counterpart, though the differences were sometimes easy to overlook, particularly by one such as Cecil Clementi. Clementi, as we have seen, spent much of his career in Hong Kong, and very much perceived the 'problem' of the Chinese in Malaya through the lens of his Hong Kong experience. When he first arrived in Malaya, he wrote almost immediately

81 Broome, 'Notes on the Chinese Protectorate'.

${ }^{82}$ Jackson, Pickering, 89.

${ }^{83}$ Letter from Tom Cromwell to A. B. Jordan, 11 Feb 1934, Tom Cromwell Papers, PP MS 33, Folder 56, SOAS Special Collections. 
to Sir Miles Lampson, who was then British Minister to China at the Peking Legation: 'It is curious how closely my Hong Kong troubles seem to have pursued me to Malaya. I must have packed them up in my baggage. ${ }^{94}$ Cases of Kuomintang activity, or even social issues such as the mui tsai (female bondservants), seemed to him to have been left on his desk in Hong Kong, and picked up afresh in Malaya. He arrived in Malaya at a critical international as well as domestic juncture. Internationally, Britain's recent recognition of Chiang Kai-shek's government in 1928 set into motion an ensuing struggle to negotiate extraterritoriality and Britain's status within China; domestically, Clementi entered a power vacuum in Malaya, taking up a governorship which had lain vacant for over half a year. Clementi arrived with a determination to curb potential trouble from Chinese communities in Malaya. Almost immediately upon arrival, he banned the KMT and placed restrictions on the vernacular press, withdrew government grants from Chinese schools, and presided over the end of free immigration in the Settlements. In part due to his policies and in part because of the extraordinary unemployment generated by the Depression, the first years of his tenure witnessed emigration exceeding immigration for the first time ever: the number of new Chinese adult male labourers entering Malaya fell from 195,613 in 1929 to 49,723 in 1931, and the colonial government spent millions to repatriate thousands of unemployed Chinese labourers back to China. ${ }^{85}$

Yet the connections Clementi adduced between Hong Kong and Malaya disposed him to perceive the two as essentially the same, and his heavy-handed approach to the governance of this multivocal community in the Straits, so unlike the relatively more homogenous Cantonese population over which he had governed in Hong Kong, made him unpopular, or, at least, amusing. Clementi was inclined to consider himself something of an authority on 'Asiatic matters'; indeed, he had even allegedly written a number of books on Chinese Affairs. But it was dangerous to assume too much congruence between Hong Kong and the Straits. Sng Choon Yee, a veteran translator in the Chinese Protectorate, recalls his first encounter with Clementi in his post as the new Governor of the Straits Settlements. Clementi had wanted them, Sng explained, to find a new word for 'police station', which in the Straits at the time was a Chinese phonetic rendering of the Malay word for police, mata-mata (Chinese: $\mathrm{mada}$ ) and which in the Cantonese Clementi was used to from Hong Kong meant 'being cursed and beaten' (罵打). Clementi suggested

${ }^{84}$ Cecil Clementi to Miles Lampson, 24 Feb 1930, Clementi Papers, Box 26, File 3.

85 Purcell, The Chinese in Malaya, 203-05. For an overview of Cecil Clementi's term, see Yong and McKenna, Kuomintang, ch. 6. 
the new word be based on the term commonly used in Hong Kong, liao which meant 'station'. Sng was horrified. Liao, it turned out, was phonetically identical to words in other Chinese dialects having to do with prostitute house and corpses. He protested. 'This won't do. That liao, I cannot turn it into a good word. It is only a bad word. Even in Hokkien, liao means pig-sty. It is just impossible. A gruesome word to use.' They settled on keng cha (jing cha), which remains the word used today. ${ }^{86}$ Sng, for his part, had not thought much of Clementi's supposed expertise in Chinese affairs. In 1930, when local newspapers had begun to clamour about Clementi's arrival as governor, Sng had been employed in the various colonial departments of Chinese Affairs for nearly 15 years. In preparation for Clementi's arrival, Sng had gotten in touch with his Jewish bookseller contact over in Cathay Wharf and instructed him to find all the books Clementi had written on Chinese Affairs, but the only book that could be located was a rather modest treatise on Cantonese love songs sung by bar girls. 'Purely colloquial,' Sng remarked blandly. ${ }^{87}$

It is in this that we find the final fact of the language technocracy, which is that despite the attempts and the qualms and the language-learning buccaneering, colonial officials still ultimately needed local expertise; Babel could not, would not be tamed without them. And it was the Chinese languages that proved the most problematic, the most complex and unintelligible, the most untameable in the eyes of a fundamentally monoglot colonial state. For to those who wished to govern, the unintelligible was not only bewildering, but threatening. The non-English or 'vernacular' press represented an unreadable, unintelligible 'empire of opinion', ${ }^{88}$ and incurred a deep, instinctive distrust almost by virtue of its non-Englishness. The British had first learned to mistrust the vernacular press in India, where there had been from the nineteenth century a definite relationship between the loss of government control over information and the government's apprehension of sedition. ${ }^{89}$ Press control laws came to Malaya with a vengeance after the 1915 Singapore Mutiny, in which 850 disaffected Indian sepoys, whose grievances were stoked in part by propaganda from the anti-British Ghadr party in the United States, rose up against the British. The matter surfaced and resurfaced in

${ }^{86}$ Sng Choon Yee, interviewed by Lim How Seng, Singapore, 5 March, 1981, SNA, OHA, accession number 000064. Hereafter Sng interview.

87 Sng interview. For Clementi's book, see Cecil Clementi, Cantonese Love-Songs (London: Clarendon, 1904).

88 C. A. Bayly, Empire and Information: Intelligence Gathering and Social Communication in India, 1780-1870 (Cambridge: CUP, 1996), 313.

${ }^{89}$ D. K. Lahiri Choudhury, 'Sinews of Panic and the Nerves of Empire: The Imagined State's Entanglement with Information Panic, India C. 1880-1912,' MAS 38, no. 04 (2004), 965-1002. 
Legislative Council meetings for years afterward. ${ }^{90}$ Those who defended the most draconian press control laws held that the non-English press was not to be trusted, that it was even inherently venal. In these as with other matters, Clementi, with his deep suspicion of the undifferentiated Chinese masses in Malaya, thought in broad, essentializing brushstrokes that were the characteristic of his regime. 'There is not in law,' Clementi conceded, 'any difference made between the English and the vernacular press; but, in point of fact, the troubles that arise are almost always confined to the vernacular press', and it was thus the vernacular press that must, he concluded, continue to see proscription and censorship. ${ }^{91}$ Clementi and others like him tended to regard Asian readers with a suspicious paternalism, believing that they were somehow more prone to extracting 'subversive meaning' out of otherwise 'perfectly harmless' books and films, and that, brought to the colonies, inoffensive literature was more 'liable to inflame the Oriental mind'. ${ }^{92}$ Ideas that could be handled with civility by the English were liable to be as dynamite in the 'vernacular spheres'. 'It would be absurd to introduce our English notions into such a community as Malaya, with its ... shifting population of ignorant \& excitable Chinese coolies,' another official wrote in $1930 .{ }^{93}$

These unsavoury stereotypes of 'ignorant and excitable Chinese coolies' betrayed the nature of colonial suspicions. Administrators who had any memory, institutional or otherwise, of the 'secret society complex' which characterized Chinese social organization harboured the deepest distrust. For many officials, vernacular, with its attendant dangers, for all intents and purposes actually meant 'Chinese'. Few 'had the language skills or cultural sensibility to perceive the Chinese as they were. ${ }^{94}$ Political developments in the 1920s appeared to lend currency to these fears. Frequent outbreaks of public demonstrations were registered throughout the decade, many of which were orchestrated by the Malayan Kuomintang movement. Authorities were sufficiently alarmed to impose a ban against it in $1925 .{ }^{95} \mathrm{In}$ that decade, the number of Chinese schools, perceived by the administration to be potential hotbeds of subversion,

${ }^{90}$ For a chronological summary of press legislation, see Yong Ching Fatt, 'The British Colonial Rule and the Chinese Press in Singapore, 1900-1941,' Asian Culture 15 (1991), 30-33.

${ }^{91}$ Letter from Clementi to Lord Passfield, 15 September 1930, TNA, CO 273/567/14; see also debate in Legislative Council Proceedings on Press Censorship in Malaya, 24 March 1930, TNA, CO 273/567/14.

${ }_{92}$ Note by J. W. D. Cocher, 8 May 1937, TNA, CO 273/633/2.

${ }_{93}$ Notes to file on press censorship in Malaya, 6 November 1930, TNA, CO 273/567/14.

${ }^{94}$ Ban Kah Choon, Absent History: The Untold Story of Special Branch Operations in Singapore, 1915-1942 (Singapore: Raffles, 2001), 97.

${ }_{95}$ See Yong and McKenna, Kuomintang, ch. 4. 
increased from 252 to 716 between 1921 and $1930 .{ }^{96}$ Chinese night schools played a major role in the Kreta Ayer incident in 1927, a violent clash in a central neighbourhood in Singapore between the police and Hainanese Kuomintang supporters on the anniversary of Sun Yatsen's death, sparked off a period of Chinese political unrest hitherto unknown in Singapore. What followed was a veritable 'orgy of raiding', during which night schools were shut down; printing presses confiscated; handbills and posters seized; Hailams detained, interrogated, and deported. The furore of police raids did not die down for four years. ${ }^{97}$

Alarmed by the unrest of the 1920s, officials who dealt frequently with the Chinese during this period spoke not only of censorship and proscription measures, but of the special venality of the Chinese language: for example, the ways in which Chinese seemed 'capable of expressing and even emphasising emphasizing an intended meaning while the written word was such as to render successful prosecution unlikely'. ${ }^{98}$ The Chinese languages were, in the prewar years, the most politicized of the languages in Malaya. In particular, Mandarin was seen as the most politicized of all the Chinese languages, since its adoption in these diasporic communities was deeply entwined with the radical project of Chinese national unification through language planning and standardization, which had been on the reform agenda of the new Republic from the very beginning. In 1920, the Beijing Ministry of Education announced that henceforth primary education was to be undertaken in the new standardized Northern Mandarin language, the single tongue of a unified China. British officers were quick to perceive new possibilities of sedition. In 1924 the teaching of Mandarin was blanket banned in all schools in Sarawak on allegations that it was full of codes and secret terms, that it was much too closely associated with clandestine political propaganda. Strenuous objections were expressed in a flurry of letters in the press: how could an entire language be deemed seditious, and banned? One writer, Z. K. Hwa, exemplified the plaintive bafflement of the bilingual speaker: 'Mandarin contains no secret terms or codes. It is quite plain Chinese .. . ${ }^{99}$ Though the ban was removed a year later, officials remained deeply suspicious of the private world of Chinese-speakers. ${ }^{100}$

${ }^{96}$ Khoo Kay Kim, 'Sino-Malay Relations in Peninsular Malaysia Before 1942,' FSEAS 12, no. 1 (1981), $98 \mathrm{n} 22$.

${ }_{97}$ For a firsthand account of the 'orgy of raiding' at Kreta Ayer, see Alec Dixon, Singapore Patrol (London: G. G. Harrap \& Co., 1935), 131-34.

98 'Ordinance for Controlling Newspapers', ST, 21 January 1920.

${ }^{9}$ Z. K. Hwa, Letter to the Editor, ST, 24 October 1924; see also C. T. F., 'Why is Mandarin Necessary?', Letter to the Editor, Singapore Free Press, 28 October 1924.

100 Notification in the Sarawak Gazette, reported in ST 26 December 1925. 
Yet the work of censorship and surveillance could not be undertaken by those European cadets who had caroused so joyfully at the Hong Kong Union while decidedly not learning Cantonese, or even those who had studied conscientiously for years, but had returned to Malaya only to realize that they still required the interpretation services of local Chinese-language speakers for the other three or four dialects they had not learned. Despite these efforts to train a European sinologue class, therefore, the situation towards the end of the 1920s was ironically one of increasing dependence on translators and interpreters. Despite the language-learning programs for European cadets, the state's native translation apparatus steadily expanded throughout the early twentieth century. In Singapore, for example, the police force at the start of the 1920s had less than ten local translators; by the end of the decade it had 21, and by the eve of the Japanese invasion it had no fewer than $57 .{ }^{101}$ This escalation was precipitated, of course, by the unrest towards the end of the 1920s, and it was mirrored in the Protectorate itself. Sng Choon Yee, who spent most of his working life in translation work at the Protectorate, recalled the day-to-day realities of the work of a censor in the late 1920s and early 1930s. The Secretariat of Chinese Affairs (SCA) building was designed specially to allow trucks loaded with crates of books and bags of mail to roll, discreetly, right into the building - 'so the public would not know' Sng explained. Books would be examined for anti-Japanese sentiments, references to controversial incidents between China and Japan, and any other so-called inflammatory material; offending sentences, passages, or even pages would be crossed out with black ink. Mail would be screened according to a list of 'mischievous' addresses supplied by the Special Branch; objectionable or banned newspapers would be extracted and destroyed, and personal letters would be withheld if they did not 'come within definitions of peace and order'. In 1930, guided by analogous practices of surveillance of the Chinese communities in the Dutch East Indies, Sng and a phalanx of Chinese translators were directed by A. M. Goodman, Protector of Chinese at the time, to digest and summarize key newspapers read by Chinese communities in Malaya, such as Shanghai's Shen Bao and the South China Morning Post, as well as locally produced papers such as the Nanyang Shangbao. All these would be extracted, recorded, and reported in the Monthly Review of Chinese Affairs, which thus evolved into an extraordinary run of serialized reports on the thoughts, actions, and writings of Chinese communities in Malaya. Indeed it became an invaluable resource for British

${ }^{101}$ Figures drawn from the Straits Settlements Establishments, 1920-1938 (Singapore: Government Printing Offices), held at the Singapore National Library. 
intelligence. Sng confided, only half-jokingly, that among his colleagues at the Protectorate, he was known as 'the fellow with his ears on the ground'. ${ }^{102}$

These were extraordinary measures, and in linguistic demand as well as in sheer volume of operations, utterly beyond the scope of the British Chinese-speaking cadets. It is in the realm of translation that we see concretely how reliant the administration thus became on intermediaries like Sng and other translators and interpreters. Ho Siak Kuan (1865-1946), another towering veteran of the Protectorate, a man of Teochew descent but raised speaking Cantonese, served for 42 years as an interpreter and later Assistant Secretary for Chinese Affairs under David Beatty. Beatty regarded Ho as the 'father of the Chinese Protectorate', and in his retirement speech, proclaimed (both in English and then in the Hokkien he had painstakingly learned over his time at the Protectorate): 'You are all aware that in a department of this kind it is not the head man who is the person who does things. The things that are done are done by his assistants, and if his assistants give him loyal and true service then a Department like this will be successful ... When I came here as a youth, ignorant and thinking that I knew a great deal more about speaking Chinese and about Chinese people as a whole than I really knew, it was Mr Siak Kwang who took me in hand and led me into the right path. ${ }^{103}$ This relationship between the Chinese language teacher and the student colonial officer, expressed so often in paternalistic terms, represented one of the very few possible avenues for a reversal of the imperial relationship - and because of this, perhaps a uniquely insecure one for the would-be tamers of a colonial Babel.

\section{Conclusion}

The great linguistic diversity of British Malaya posed profound challenges to the colonial state's ability to govern it. Attempts to meet these challenges were to a large extent undertaken through the piecemeal creation of a language technocracy: an administration shaped and underpinned by linguistic needs. Yet, as the British were discovering in parallel in Africa, conquering land was easy: administering it was not. The modern imperial state was a thin administrative layer, given a little flesh by advanced capitalism and kept in stasis by 'a civilizing mission [which] ended up supporting conservative chiefs and worrying that too much

102 Sng interview.

103 'Mr. David Beatty: Presentation of Address from Chinese Community', ST, 21 October 1926; see also Singapore Free Press, 21 October 1926. 
social change would compromise order' ${ }^{104}$ A consistent theme throughout this early- to high-colonial period is the coexistence of distrust and dependence on speakers who could help in the task of taming Babel. Chinese languages were perceived as the most dangerous, unruly, and in need of taming. Yet the attempted solutions to the problem of distrust the creation of a European Chinese-speaking cadre of officers - exposed other tensions within the colonial state. The prestige and qualifications to governance of European officers were compromised, exposed by the travails of language learning and the business of governing populations they could not easily speak to. The reversal of colonial paternalism was a difficult reality to negotiate. And even when the languages began to be learned, through a reshaping of the technocracy to meet the ever-more painfully perceived language shortfall, their best efforts were insufficient; the linguistic complexity of the Chinese communities in Malaya still defied easy governance, and the British colonial state was never able to wean itself from full dependence on its intermediaries. These tensions at the heart of the imperial project would shape the British administration's perceptions of both the coherence and the dangerous quality of 'the Chinese' in British Malaya.

The British attitude to the Malay language was far more proprietary, as we will see. If knowledge of Chinese communities and their numerous languages brought ever more intimate knowledge of the threatening ungovernability of their subjects, knowledge of Malay, I suggest, entailed governability. When it came to Malay, the technocratic colonial state did something that it was never able to for Chinese languages: it claimed to know Malay better than those who spoke it. We turn now to the knowledge producers.

${ }^{104}$ Jane Burbank and Frederick Cooper, Empires in World History: Power and the Politics of Difference (Princeton, NJ: Princeton University Press, 2010), 316. 